\title{
METHOD OF INDICATING EFFECTIVE CIRCUMFERENCES OF ROLLING VEHICLE WHEELS
}

\author{
Michał JANULIN \\ University of Warmia and Mazury in Olsztyn, Faculty of Technical Sciences, Department of Vehicle \\ and Machine Operation Construction, Chair of Vehicles and Machinery Exploitation, \\ michal.janulin@uwm.edu.pl
}

\begin{abstract}
Determining the exact values of the rolling radii of the wheels is extremely important in terms of the functioning of the safety systems of modern vehicles. It is on the basis of the rotational speed of the vehicle wheels that the traction parameters of the vehicle are determined, as well as the warning about the existence of low tire pressure. The precision of determining the turning radius significantly improves the accuracy of calculations of the slip value, driving force, and also plays a key role in determining the linear speed of a motor vehicle. This article presents the method of determining the value of the rolling radius of a tire and tests of changes in its value under the influence of changes in the value of vertical load and tire pressure. Based on the performed measurements, a mathematical model of changes in the value of the effective wheel rolling circumference from the above-mentioned parameters was determined. The results of the regression analysis indicate a very good fit of the developed model to the results of the conducted experimental research.
\end{abstract}

Keywords: turning radius of the wheel, wheel load, tire pressure.

\section{METODA WYZNACZANIA EFEKTYWNYCH OBWODÓW TOCZENIA KÓŁ POJAZDÓW}

\section{Streszczenie}

Określenie dokładnych wartości promieni toczenia kół jest niezwykle istotne w aspekcie funkcjonowania systemów bezpieczeństwa nowoczesnych pojazdów. To na podstawie prędkości obrotowych kół pojazdu określane są parametry trakcyjne pojazdu, jak również generowane jest ostrzeżenie o byt niskim ciśnieniu w ogumieniu. Precyzja określania promienia toczenia wpływa na znaczną poprawę dokładności obliczeń wartości poślizgu, siły napędowej, jak również odgrywa kluczową rolę w przypadku określania liniowej prędkości ruchu pojazdu samochodowego. W niniejszym artykule przedstawiono metodę wyznaczania wartości promienia toczenia koła ogumionego oraz przeprowadzono badania zmian jego wartości pod wpływem zmian wartości obciążenia pionowego oraz ciśnienia w ogumieniu. Na podstawie przeprowadzonych pomiarów, wyznaczono model matematyczny zmian wartości efektywnego obwodu toczenia koła od wymienionych parametrów. Wyniki analizy regresji wskazują na bardzo dobre dopasowanie opracowanego modelu do wyników przeprowadzonych badań eksperymentalnych.

Słowa kluczowe: promień toczenia koła, obciążenie koła, ciśnienie w ogumieniu.

\section{INTRODUCTION}

Research on rolling radius on various road surfaces has been the subject of discussions and scientific studies for many years $[10,13,15,17,18$, $21,22,23]$. Determining the exact value of rolling radius influences the considerable improvement in the exactness of skid value calculation and drive force and plays a key role in the determination of a vehicle's linear movement speed [19]. Due to the importance of change in the value of a vehicle's wheel rolling radius in varied conditions of vertical wheel load, GPS instruments are often used for registering linear speed [4, 8, 15]. Also of considerable importance is the influence of a vehicle's wheel rolling radius value on the functioning of active safety systems, which collect information on the rotational speeds of individual wheels.

Often, in the case of simple calculations, dependencies estimating wheel rolling radius value based on the free radius value are used. However, such an approach is burdened with considerable error [1]. In the 1980s, Upadhyaya et al. (1988) conducted numerous studies on the traction characteristics of agricultural vehicles. In one paper, a reference was made to a standard defining the rolling radius as being the distance covered through one rotation of a wheel during operation with zero-value net grip, zero-value net torque, divided by $2 \pi$. The drawback of the approach presented in the paper is the assumption that rolling radius is a constant value, which may be determined in quasi-static conditions, as done by Kiss (2003), or that a large amount of empirical 
data is needed for determining 'actual rolling radius' or 'actual skid value', as done by Upadhyaya et al. (1988). The character of those studies was also limited to soft surface areas (deformable), where movement dynamics is of less importance, and the quasi-static approach of Kiss (2003) makes it possible to obtain results of satisfactory accuracy.

Kiss (2003) examined three types of agricultural vehicle tyre radii, i.e. the distance between the ground and the centre of a wheel, kinematic rolling radius defined by the movement (skid) and kinetic rolling radius (often defined by tyre manufacturers). These measurements were conducted with various tyre pressures on sandy clay soil. The presented measurements were based on the registration of vertical wheel displacement and the dynamic radius was assumed to be the distance from the centre of the wheel to the road surface. The kinematic rolling radius was defined as a skid function and determined with an equation with various skid values:

where:

$$
r_{s}=\frac{l}{2 \pi}
$$

$l$ - distance covered during one wheel rotation.

If a wheel is rolling without skid, the kinematic radius of a rigid wheel equals its geometrical radius. When the skid value is positive (driven wheel), the kinematic radius decreases, while during braking (negative skid) the radius value increases [3, 7]. It is not, however, clear, how the tyre skid was determined. The kinetic rolling radius acts in the vicinity of the contact point of a rolling tyre and deformable surface. This is the distance between the centre of a wheel and resultant elementary tractive forces, acting along the contact surface with the ground [9]. Its value determines the tractive force extent $\left(F_{n}\right)$, generated by the driving momentum delivered to a wheel $\left(M_{n}\right)$. Thus, its value may be presented as:

$$
r_{\text {kin }}=\frac{M_{n}}{F_{n}}
$$

4WD vehicles constitute an increasingly numerous group of vehicles bought by private owners. These are structures which often use the system of automatic disconnection of the second axle in the event of detecting a skid in any of the driven wheels; however, these types of systems are not suitable for operating in difficult terrain conditions. For off-road vehicles, the most favourable solution is still fixed power transmission to both axles, executed via an inter-axle differential mechanism [6, 16]. For such systems, it is of utmost importance to avoid situations in which kinematic discrepancies emerge between driving axles, as all differences in rotational speeds of drive shafts generate additional energy losses and increase fuel consumption [12, 24]. Thus, the key parameters influencing the operation of 4WD systems are the effective rolling circumference (EOT) of both drive axle's wheels [11, 12]. For the purpose of this paper, it has been assumed that the EOT value of a wheel is connected with the wheel's kinematic radius, determined with the dependency:

$$
E O T=2 \pi \cdot r_{s}
$$

which, following a reduction, results in:

$$
E O T=l
$$

The main factors influencing the change of EOT value is the vertical load of each wheel and tyre pressure [2, 20]. Therefore, vehicle manufacturers provide - in instruction manuals, as well as in type plate in a vehicle - information about the need to correct values in tyre pressure, conditioned by the distribution and number of transported passengers or an amount of cargo. Nevertheless, this information is imprecise and, thus, even when observed, the problem of generation of stresses and losses in the drive system is not minimised, but merely reduced.

In each differential mechanism, there is the socalled internal friction momentum, which may be determined with the following equation [5]:

$$
M_{T}=M_{o p}-M_{p r}
$$

where:

$M_{o p}$ - drive momentum at the delayed axle,

$M_{p r}$-drive momentum at the accelerated axle.

This shows that only the difference of drive momentum values, delivered to the delayed and accelerated axles, exceeding the internal friction momentum, may cause the inter-axle differential mechanism to operate. A difference value lower than the internal friction momentum hinders the operation of the differential mechanism and the drive system acts as in the case of a fixed connection between drive axles. Generally, it is accepted that the internal friction momentum of the differential mechanism is a variable value and it may be treated as a sum of two components [5]:

where:

$$
M_{T}=M_{d o t}+k \cdot M_{w n}
$$

$M_{d o d}$ - friction momentum with a fixed value present in the differential mechanism,

$M_{w m}$ - momentum is delivered to the differential mechanism,

$k$ - coefficient of the coupling momentum.

In this paper, the method of determining changes in the EOT value is presented, conditioned by the value of vertical load and vehicle's tyre pressure, which, in turn, served the purpose of elaborating a mathematical model which may be used in simulation models and for optimisation of air pressure values in tyres of actual vehicles.

\section{RESEARCH METHODOLOGY}

Research on EOT values changes were conducted in two stages: 
- identification of a vehicle's weight distribution to the front and rear axle, depending on the variant of vehicle load.

- determination of effective circumferences of wheel rolling, depending on the variant of vehicle load and tyre pressure used.

The experiment's diagram (with consideration for the first and second stage of the research) used for determining the effective rolling circumference is presented in Fig. 1.

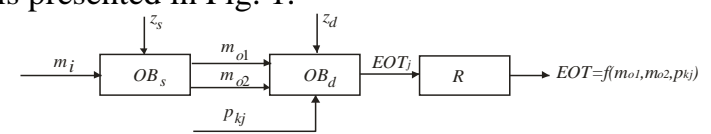

Fig. 1. The experiment's diagram of determining the effective rolling circumference: $\mathrm{mi}$ - ith variant of vehicle load; OBs - research subject at Beissbarth STL 7000 station; OBd - research subject in road conditions, mo1,2 — weight falling for the front and rear axle; EOTj - effective rolling circumference of $\mathrm{jth}$ wheel, $\mathrm{p}_{\mathrm{kj}}$ pressure in $j$ th wheel; $z_{\mathrm{s}}$ - interferences stemming from tests at Beissbarth STL 7000 station; $\mathrm{z}_{\mathrm{d}}$ - interferences stemming from road tests; $\mathrm{R}$ - determination of repeated regression

The first stage of research was conducted at a Beissbarth STL 7000 station and consisted of determining the weight distributions for individual vehicle axles, depending on the adopted load variants. Diagrams of weight distributions for individual load variants are presented in Fig. 2, where the following were considered:

a) a vehicle with a driver;

b) a vehicle with a driver and a passenger in the front seat;

c) a vehicle with a driver and a passenger in the front seat and one passenger in the back seat;

d) a vehicle with a driver and a passenger in the front seat and two passengers in the back seat;

e) a vehicle with a driver and a passenger in the front seat and three passengers in the back seat;

f) a vehicle with a driver and a passenger in the front seat, three passengers in the back seat and luggage in a trunk;

When selecting the weight of a driver and passengers, it was attempted to measure the average values for people travelling in a vehicle, i.e. approx. $75 \mathrm{~kg}$; and the weight of the luggage was adopted as $65 \mathrm{~kg}$.

In the second research stage, the EOT value was determined with an indirect method, using the measuring track consisting of a CORREVIT S-350 Aqua system and an ARC-5-250-TTL-6 encoder (Fig. 3).

CORREVIT S-350 Aqua system is a 2-axis sensor designed for skid-less measurements of a vehicle's longitudinal and lateral dynamics. It makes it possible to register parameters like

distance, speed and acceleration. The measuring head generates signals with $250 \mathrm{~Hz}$ frequency. For the measurement of effective wheel circumference, it is indispensable to register the distance of travel and the number of executed wheel rotations - both with a common

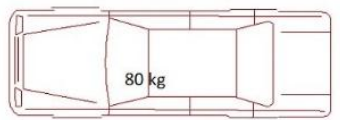

c.
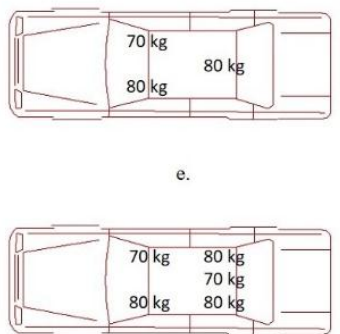

Fig. 2. Weight distribution diagrams for tests at Beissbarth STL 7000 station. Load variants (from a. to f.) according to the adopted load scenario

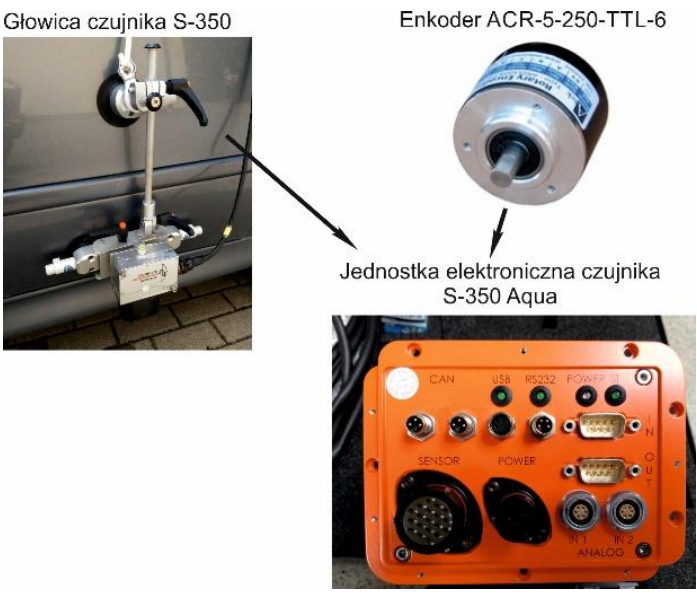

Fig. 3. View of the measuring track consisting in CORREVIT S-350 Aqua system and ARC-5-250-TTL-6 encoder

time base. The number of rotations was measured with an ARC-5-250-TTL-6 encoder. The encoder was fixed coaxially with the vehicle's drive wheel. When the vehicle was in motion, the generated signal from encoder's A-line was relayed to counter's input of the CORREVIT S-350 Aqua measurement system. A measuring track configured this way makes it possible to register the covered distance with an accuracy of $\pm 0.2 \%$. Based on the technical specifications of the measuring track, it was assumed that during the measurements the test section should be longer than $200 \mathrm{~m}$ (the minimum distance required for reaching the assumed accuracies) and the vehicle's speed should reach approx. $60 \mathrm{~km} \cdot \mathrm{h}^{-1}$. The beginning and the end of the measuring section were triggered using the laptop's 
keyboard, connected with a USB port with the CORREVIT S-350 Aqua measuring system's electronic unit. The measurements were conducted on a smooth road with an asphalt surface.

The effective wheel rolling circumference was determined with the equation:

$$
E O T=\frac{z \cdot l_{x}}{i}[m]
$$

where:

$z$ - number of pulses generated for one full rotation (encoder's constant),

$l_{x}$ - covered distance over the measuring section [m],

$i$ - number of pulses generated by the encoder.

In the experimental test schedule it was assumed for each of vertical load variants that there would be tests conducted with changed values of pressure in wheel tyres of the tested vehicle (Table 1), observing the assumptions:

- for front axle wheels, four values of the vehicle's wheel tyre pressures were assumed for each load variant,

- for rear axle wheels, three values of vehicle's wheel tyre pressures were assumed for each load variant, and there was a rule adopted that pressure values increase together with the increase in vertical wheel load.

Table 1. Pressure values in wheels during road tests

\begin{tabular}{|c|c|}
\hline Type of wheels & $\begin{array}{c}\text { Pressure value in } \\
\text { wheels [kPa] }\end{array}$ \\
\hline Front axle wheels & $200,240,280,320$ \\
\hline $\begin{array}{c}\text { Rear axle wheels - } \\
\text { axle load variant 1 }\end{array}$ & $180,220,260$ \\
\hline $\begin{array}{c}\text { Rear axle wheels - } \\
\text { axle load variant 2 }\end{array}$ & $200,240,280$ \\
\hline $\begin{array}{c}\text { Rear axle wheels - } \\
\text { axle load variant 3 }\end{array}$ & $220,260,300$ \\
\hline $\begin{array}{c}\text { Rear axle wheels - } \\
\text { axle load variant 4 }\end{array}$ & $240,280,320$ \\
\hline
\end{tabular}

For each combination of pressure value and axle load, the measurement was executed three times, to eliminate possible errors and average the results.

For processing of the EOT experimental test results, the repeated regression analysis was employed [14]. For the purpose of describing the dependency, the classical linear regression model was adopted in the form of:

$$
\begin{aligned}
& y_{i}=b_{0}+b_{1} x_{i 1}+b_{2} x_{i 2}+\cdots+b_{k} x_{i k}+ \\
& e_{i}, \quad i=1,2, \ldots, n
\end{aligned}
$$

and for $e_{i}$ random component it was assumed that: $E\left(e_{i}\right)=0$,

$D^{2}\left(e_{i}\right)=\sigma^{2}$,

$\operatorname{cov}\left(e_{i}, e_{i}^{\prime}\right)=0$ for $i \neq i^{\prime}$ (cov being covariance).

The $b_{i}$ regression coefficient was estimated with the least-squares method, minimising the sum of squares $S\left(b_{1}, b_{2}, \ldots b_{k}\right)$, where:

$$
\begin{aligned}
S\left(b_{0}, b_{1}, b_{2}, \ldots, b_{k}\right) & \\
& =\sum_{i=1}^{n}\left(y_{1}-b_{0}-b_{1} x_{i 1}\right. \\
& -b_{2} x_{i 2}-\cdots \\
& \left.-b_{k} x_{i k}\right)^{2}, i=1,2, \ldots, n
\end{aligned}
$$

Let the estimated form of the linear regression model be:

$$
\begin{gathered}
\widehat{y_{l}}=\widehat{b_{0}}+\widehat{b_{1}} x_{i 1}+\widehat{b_{2}} x_{i 2}+\ldots+\widehat{b_{k}} x_{i k}, i \\
=1,2, \ldots, n
\end{gathered}
$$

Differences $\widehat{e}_{l}=y_{i}-\widehat{y}_{l}$ are the model's remainders. The remainders are the difference between empirical and theoretical values of the regression function. They characterise the fitness of the model to the observed data. Based on them, the so-called remainder variance is calculated.

$$
\begin{aligned}
S S E=\frac{\sum_{j=1}^{n} e_{i}^{2}}{n-k-1} & =\frac{\sum_{j=1}^{n}\left(y_{i}-\widehat{y}_{l}\right)^{2}}{n-k-1} \\
& =\frac{S S Y-\frac{(S X Y)^{2}}{S S X}}{n-k-1}
\end{aligned}
$$

where:

$$
\begin{aligned}
& S S Y=\sum_{i=1}^{n} y_{i}^{2}-\frac{\left(\sum_{i=1}^{n} y_{i}\right)^{2}}{n} \\
& S S X=\sum_{i=1}^{n} x_{i}^{2}-\frac{\left(\sum_{i=1}^{n} x_{i}\right)^{2}}{n} \\
& S X Y=\sum_{i=1}^{n} x_{i} y_{i}-\frac{\sum_{i=1}^{n} x_{i} \sum_{i=1}^{n} y_{i}}{n}
\end{aligned}
$$

As the measure of the model's fitness for empirical data, the coefficient of termination $R^{2}$ was adopted in the form of:

$$
R^{2}=\frac{S X Y^{2}}{S S X \cdot S S Y}
$$

The coefficient assumes a value from the interval of $\langle 0 ; 1\rangle$. It defines, what part of the observed variance of a $\mathrm{Y}$ feature was explained with the use of the adopted model.

For the verification of zero theory $H_{0}: b_{1}=b_{2}$ $=\ldots=b_{k}=0$, with significance of regression coefficients, against the alternative hypothesis $H_{l}$ : $\neg\left(b_{1}=b_{2}=\ldots=b_{k}=0\right)$, the $F$ statistics was used in the form of:

$$
F=\frac{V r}{V e}
$$

where $V_{r}$ and $V_{e}$ are given in Table 2 and express mean squares for the model and the error.

The F statistics with the truth of zero hypothesis features Snedecor's F distribution with $\mathrm{k}$ and (n-k-1) degrees of freedom. The critical area for these statistics is constructed on the right. 
Table 2. Variance analysis chart for a repeated regression model

\begin{tabular}{|l|c|c|c|}
\hline Source of variance & Freedom degrees & Sum of squares & Mean square \\
\hline Regression & $K$ & $S S R$ & $V r=\frac{S S R}{k}$ \\
\hline Error & $n-k-1$ & $S S E$ & $V e=\frac{S S E}{n-k-1}$ \\
\hline Total & $n-1$ & $S S C$ & --- \\
\hline
\end{tabular}

where: $S S C=S S Y, S S R=\frac{(S X Y)^{2}}{S S X}, S S E=S S C-$ SSR.

Since two explanatory variables were used for the determination of EOT model

$\left(p_{k j}\right.$ - pressure in the examined wheel and $m_{o l}$ weight falling for the axle of the examined wheel), the regression model assumes the form of:

$$
E O T_{j}=b_{0}+b_{1} p_{k j}+b_{2} m_{o l}
$$

Assumptions:

- the model is linear against the parameters;

- explanatory variables are not random;

- the $n$ number of observations must be larger than the number of estimated parameters i.e. $n>k+1$;

- none of the independent variables are a linear combination of other independent variables;

- the $e_{i}$ random components feature the expected value equalling zero for all $i$;

- variance of the random component is the same for all observations;

- random components (remainders) are not correlated;

- each of the random components features normal distribution.

WINSTAT software was used to determine the model and verify the hypotheses.

\section{RESEARCH RESULTS AND ANALYSIS}

During the first research stage, the distribution of weights, falling for individual vehicle's axles, was determined. The results of the conducted measurements are presented in Table 3.

Table 3. Measurement results of weight falling for vehicle's axles

\begin{tabular}{|c|c|c|c|}
\hline \multirow{2}{*}{$\begin{array}{c}\text { Designation } \\
\text { of load } \\
\text { variant }\end{array}$} & \multicolumn{3}{|c|}{ Weight } \\
\cline { 2 - 4 } & front $[\mathrm{kg}]$ & rear $[\mathrm{kg}]$ & total $[\mathrm{kg}]$ \\
\hline a. & 920 & 720 & 1.640 \\
\hline b. & 955 & 755 & 1.710 \\
\hline c. & 975 & 820 & 1.795 \\
\hline d. & 990 & 885 & 1.875 \\
\hline e. & 1.005 & 940 & 1.945 \\
\hline f. & 960 & 1.150 & 2.110 \\
\hline
\end{tabular}

Based on the results provided in Table 3, it was shown that the operational load of a vehicle spurs the distribution of weights onto the front axle in the range of $920-1.005 \mathrm{~kg}$, and onto the rear axle in the range of $720-1.150 \mathrm{~kg}$. It may be also noted that despite an increase in the total weight in the last variant, there was a decrease in the front axle load when compared to the 'e' variant.

Knowing the vertical load of front and rear axle, as well as suitable pressure (following Table 1), the measurements of effective rolling circumferences (EOT) of the vehicle wheels were conducted. Over the course of runs in the function of time, the distance and the number of pulses per test section were registered. The sample measurement results of the covered distance for the time of 100 rotations and the calculated EOT values are presented in Table 4.

Table 4. Exemplary test results of EOT for the left front

\begin{tabular}{|c|c|c|c|c|c|}
\hline \multirow{2}{*}{$\begin{array}{l}\text { Weight/ } \\
\text { Axle }\end{array}$} & \multirow[b]{2}{*}{ Test } & \multicolumn{4}{|c|}{ Wheel pressure for the examined axle } \\
\hline & & $200 \mathrm{kPa}$ & $240 \mathrm{kPa}$ & $280 \mathrm{kPa}$ & $320 \mathrm{kPa}$ \\
\hline \multirow{5}{*}{$925 \mathrm{~kg}$} & 1 & $192.980 \mathrm{~m}$ & $193.420 \mathrm{~m}$ & $193.600 \mathrm{~m}$ & $194.000 \mathrm{~m}$ \\
\hline & 2 & $192.940 \mathrm{~m}$ & $193.300 \mathrm{~m}$ & $193.680 \mathrm{~m}$ & $193.860 \mathrm{~m}$ \\
\hline & 3 & $193.060 \mathrm{~m}$ & $193.320 \mathrm{~m}$ & $193.700 \mathrm{~m}$ & $193.840 \mathrm{~m}$ \\
\hline & mean & $192.993 \mathrm{~m}$ & $193.347 \mathrm{~m}$ & $193.660 \mathrm{~m}$ & $193.900 \mathrm{~m}$ \\
\hline & EOT & $1.930 \mathrm{~m}$ & $1.933 \mathrm{~m}$ & $1.937 \mathrm{~m}$ & $1.939 \mathrm{~m}$ \\
\hline \multirow{5}{*}{$1.000 \mathrm{~kg}$} & 1 & $192.900 \mathrm{~m}$ & $193.160 \mathrm{~m}$ & $193.400 \mathrm{~m}$ & $193.600 \mathrm{~m}$ \\
\hline & 2 & $192.900 \mathrm{~m}$ & $193.100 \mathrm{~m}$ & $193.400 \mathrm{~m}$ & $193.640 \mathrm{~m}$ \\
\hline & 3 & $192.800 \mathrm{~m}$ & $193.100 \mathrm{~m}$ & $193.500 \mathrm{~m}$ & $193.700 \mathrm{~m}$ \\
\hline & mean & $192.867 \mathrm{~m}$ & $193.120 \mathrm{~m}$ & $193.433 \mathrm{~m}$ & $193.647 \mathrm{~m}$ \\
\hline & EOT & $1.929 \mathrm{~m}$ & $1.931 \mathrm{~m}$ & $1.934 \mathrm{~m}$ & $1.936 \mathrm{~m}$ \\
\hline
\end{tabular}

The results of the repeated regression analysis for the EOT model were presented in the form of a report generated by the WINSTAT software in Fig. 4.

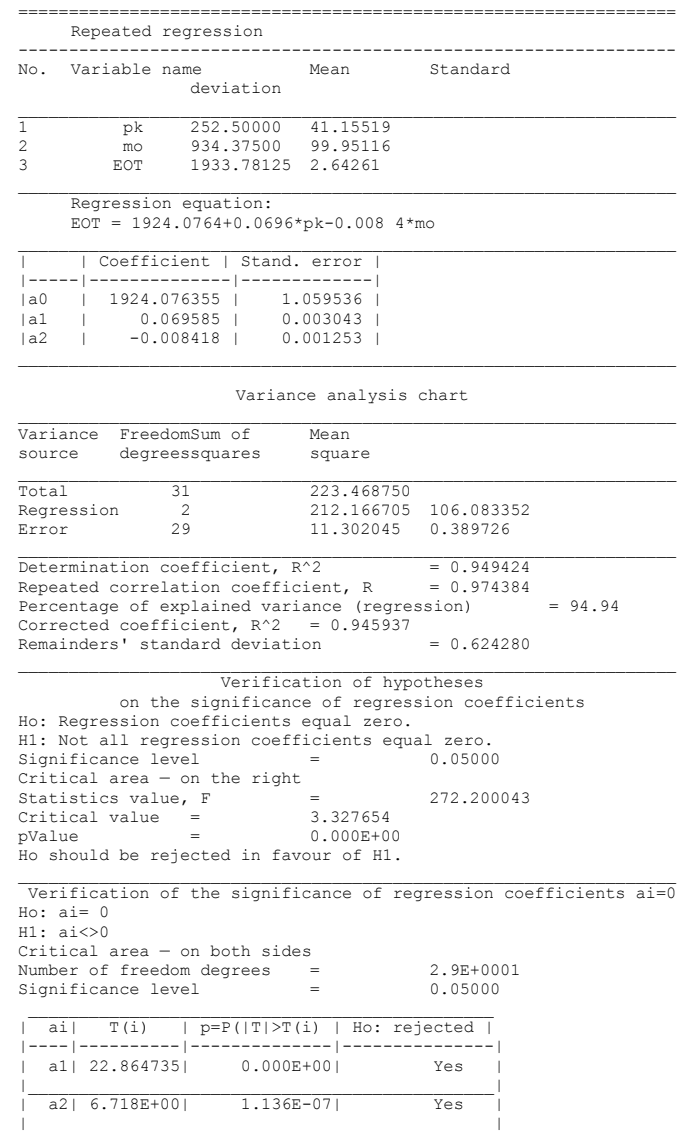

Fig. 4. The WINSTAT software report with repeated regression results for the model of EOT changes 
The regression analysis results indicate the very good fit of the model to the results of experimental tests; the R2 determination coefficient amounted to 0.95. The verification of significance of the influence of regression coefficients indicates that both the vehicle's axle load and the tyre pressure were significant.

The elaborated repeated regression model for determining the values of effective wheel rolling circumference was noted as:

$$
\begin{array}{r}
E O T=1924,0764+0,0696 \cdot p_{k} \\
-0,0084 \cdot m_{o}[\mathrm{~m}]
\end{array}
$$

where:

$p_{k}$ - wheel pressure for a given axle (front or rear) in $[\mathrm{kPa}]$

$m_{o}$ - weight falling for wheels of a given axle in [kg].

\section{CONCLUSIONS}

With the presented method for testing effective wheel rolling circumferences, it is possible to elaborate the regression model, allowing for high accuracy determination of EOT value, and thus also of the dynamic radii of vehicle's wheels based on the vertical load of the drive axles and the tyre pressure. When elaborating such models for various tyre sizes, one may build a knowledge base, which could be used by vehicle users to select the optimum tyre pressure values and for equipping a vehicle's design with simple sensors and implementing the elaborated models in software for its operation. In this way, a system could be developed, which, based on the compression of elastic suspension elements, would estimate the vertical load of a given drive axle and, using the interface, could inform the user about exact tyre pressure values, recommended with a given vehicle's load. This would certainly influence the minimization of losses in 4WD systems and would influence the safety of vehicle's users due to retention of constant proportions of torque distribution between the drive axles of vehicles equipped with inter-axle differential mechanisms of various designs. The elaborated mathematical model of EOT changes in the function of vertical load and tyre pressure was used in the simulation model of a 4WD vehicle.

\section{REFERENCES}

1. Balakina EV, Lipatov EY, Sarbayev D S. Advantages of using wheel rolling radius for calculating friction characteristics in wheel-to-road contact patch. In: International Conference on Industrial Engineering. Springer, Cham. 2019:1015-1022.

https://doi.org/10.1007/978-3-030-22041-9_107.

2. Bosch HRB, Hamersma HA, Els PS. Parameterisation, validation and implementation of an all-terrain SUV FTire tyre model. Journal of Terramechanics. 2016; 67:11-23. https://doi.org/10.1016/j.jterra.2016.06.001.
3. Butsch M, Dettling J, Ritz C, Wizgall A. Tests with a Dynamometer Related to the Determination of Energy Consumption, Dynamic Behavior and Slippage of Vehicles. SAE Technical Paper, 2019. https://doi.org/10.4271/2019-26-0352.

4. Celiński I. Mobile diagnostics of vehicles as a means to examine and define speed limits in a road. Diagnostyka. 2017;18(1):67-72.

5. Dębicki M. Teoria samochodu-teoria napędu; Wydawnictwa Naukowo-Techniczne, Warszawa 1969.

6. Dębowski A. Modelling of centre differential control. Journal of KONES Powertrain and Transport. 2011; 18(1): 135-142.

7. Fayyad SM, Rawashdeh MO. Factors affect slipping of automobiles. WSEAS Trans. Syst. Control 2020;15:247-253. https://doi.org/10.37394/23203.2020.15.26

8. Grytsyuk O, Vrublevskyi O. Investigations of diesel engine in the road test. Diagnostyka, 2018;19:89-94. https://doi.org/10.29354/diag/90279

9. Hamersma HA, Botha TR, Els PS. Kinetic vs. Kinematic Roll Radius on Rough Roads. In: Proceedings of the 18th International Conference of the ISTVS, Seoul, Korea. 2014:69-80.

10. Kiss P. Rolling Radii of a Pneumatic Tyre on Deformable Soil, Biosystems Engineering. 2003; 85(2):153-161. https://doi.org/10.1016/S15375110(03)00043-6.

11. Kolator B, Janulin M, Vrublevskyi O. Influence of traction conditions on the power balance in the vehicle 4WD system. In: IOP Conference Series: Materials Science and Engineering. 2018.

12. Kolator B, Janulin M, Vrublevskyi O. Effect of a Torsen Differential Mechanism on Car Tyre Wear. Tribologia. 2018;4:31-37. https://doi.org/10.5604/01.3001.0012.7482.

13. Kutzbach HD, Bürger A, Böttinger S. Rolling radii and moment arm of the wheel load for pneumatic tyres. Journal of Terramechanics. 2019; 82: 13-21. https://doi.org/10.1016/j.jterra.2018.11.002.

14. Mikołajczak J. Statystyka matematyczna z pakietem WinStat. Wydawnictwo UWM, Olsztyn 2001.

15. Miller SL, Youngberg B, Millie A, Schweizer P, Gerdes JC. Calculating longitudinal wheel slip and tire parameters using GPS velocity. In: Proceedings of the 2001 American Control Conference.(Cat. No. 01CH37148). IEEE, 2001: 1800-1805. https://doi.org/10.1109/ACC.2001.945995.

16. Naunheimer H, Bertsche B, Ryborz J, Novak W. Automotive Transmissions: Fundamentals, Selection, Design and Application. Second Edition. Springer: Heidelberg, Dor-drecht, London, New York. 2011.

17. Oh J, Nam J, Kim S, Park, Y. Influence of tire inflation pressure on the estimation of rating cone index using wheel sinkage. Journal of Terramechanics. 2019; $\quad 84: \quad$ 13-20. https://doi.org/10.1016/j.jterra.2019.04.002.

18. Pedrycz N, Cieślikowski B, Frączek J, Ślipek Z, Francik S. Badania trakcyjne samochodu wyposażonego $\mathrm{w}$ pośredni system pomiaru ciśnienia w kołach. Logistyka. 2015; 4: 5278-5283.

19. Šarkan B, Skrúcaný T, Semanová Š, Madleňák R, Kuranc A, Sejkorová M, Caban J. Vehicle coastdown method as a tool for calculating total resistance for the purposes of type-approval fuel consumption. Scientific Journal of Silesian University of 
Technology. Series Transport. 2018; 98: 161-172 https://doi.org/10.20858/sjsutst.2018.98.15.

20. Szczucka-Lasota B, Kamińska J, Krzyżewska I. Influence of tire pressure on fuel consumption in trucks with installed tire pressure monitoring system (TPMS). Scientific Journal of Silesian University of Technology. Series Transport. 2019;103:167-181. https://doi.org/10.20858/sjsutst.2019.103.13.

21. Upadhyaya SK, Chancellor WJ, Wulfsohn D. Sources of variability in traction data. Journal of Terramechanics. 1988; 25(4):249-272, https://doi.org/10.1016/0022-4898(88)90040-7.

22. Warczek J. Metoda pomiaru promienia dynamicznego koła samochodowego. Zeszyty Naukowe. Transport/Politechnika Śląska. 2010; 67: 97-103.

23. Žuraulis V, Garbinčius G, Skačkauskas P, Prentkovskis O. Experimental study of winter tyre usage according to tread depth and temperature in vehicle braking performance. Iranian Journal of Science and Technology, Transactions of Mechanical Engineering. 2020;44.1:83-91. https://doi.org/10.1007/s40997-018-0243-0.

24. Żebrowski J. Metodyka określania efektywności funkcjonowania ciągnika terenowego. Prace Naukowe, Mechanika. Politechniki Warszawskiej. 2004.

Received 2020-07-22

Accepted 2020-11-18

Available online 2020-11-19

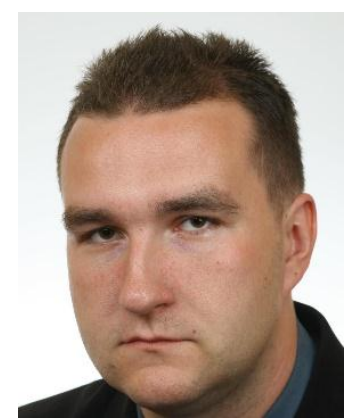

Ph.D., Eng Michal

JANULIN works in the Department of Vehicle and Machine Construction and Operation at the Faculty of Technical Sciences. He deals with issues associated with the construction, operation and diagnostics of vehicles. 